\title{
Impact of Biologically Treated Effluent on the Physico-chemical Quality of a Receiving Stream in Ile-Ife, Southwest Nigeria
}

\author{
Godwin Irabor Asibor ${ }^{1}$, Edjere Oghenekohwiroro ${ }^{1} \&$ Funso Adeniyi ${ }^{2}$ \\ ${ }^{1}$ Department of Environmental Sciences, College of Science, Federal University of Petroleum Resources, Effurun, \\ Nigeria \\ ${ }^{2}$ Department of Zoology, Obafemi Awolowo University, Ile-Ife, Nigeria \\ Correspondence: Godwin Irabor Asibor, Department of Environmental Sciences, College of Science, Federal \\ University of Petroleum Resources, P.M.B. 1221, Effurun, Delta State, Nigeria. E-mail: \\ asibor.godwin@fupre.edu.ng
}

Received: March 10, 2015 Accepted: June 22, 2015 Online Published: September 27, 2015

doi:10.5539/jsd.v8n8p213 URL: http://dx.doi.org/10.5539/jsd.v8n8p213

\begin{abstract}
This study was carried out to investigate the impact of biological treated effluent on the physico-chemical properties of receiving waterbodies and also to establish its suitability for other purposes. It focused on the changes of some physic-chemical variables as one move away from the point of discharge downstream of the waterbodies. Water samples were collected from 14 sampling stations made up of the untreated effluent, treated effluent and receiving streams (before and after treated effluent discharge) over a period of 6 months spanning the dry and rainy seasons. Analyses were carried out on the following: temperature, turbidity, $\mathrm{pH}$, conductivity, major anions and cation, dissolved oxygen, percentage oxygen Saturation, biological oxygen demand (BOD), solids (total solids, suspended solids and dissolved solids), nitrates, phosphates, organic matter and flow discharge using standard analytical methods.

The relationships between investigated sites with regards to their physico-chemical properties were analyzed using student-t statistics. Also changes in the treated effluent receiving streams after treated effluent outfall was discussed fully.

The physico-chemical water quality of the receiving water bodies meets most of the general water requirements for both domestic and industrial uses. The untreated effluent quality was shown to be of biological origin based on the biological oxygen demand, chloride, dissolved oxygen, total solids, $\mathrm{pH}$ and organic matter. The treated effluent showed significant improvement over the raw untreated effluent based on most parameters assessed.

There was a significant difference $(\mathrm{p}<0.05)$ between the physico-chemical quality of untreated effluent and the treated effluent for the most of the investigated physico-chemical quality. The difference between the discharged treated effluent and the unimpacted section of the receiving waterbodies was also significant $(p<0.05)$ for the most of the physico-chemical parameters.
\end{abstract}

Keywords: physico-chemical, effluent, waterbody, impact, Opa River

\section{Introduction}

The problem of waste generation and management in developing countries is a major concern to government and has become worrisome in Nigeria in recent times due to increase in population with its attendant socio-economic factors (Butu and Mshelia, 2014). Omole and Alakinde (2013), Abila and Kantola (2013) and Kadafa et al (2013) are of the view that waste management problems in Nigeria cut across human health, air, water and land pollution. Miller (1994) defines waste as man's unwanted materials that need to be discarded; while Ogedengbe (1990) defines wastewater (a subset of waste) as any water which has been rendered unfit for intended purposes due to various forms of use and abuse. The term wastewater covers broadly domestic and industrial liquid wastes as well as storm run-off. The strength of wastewater is commonly expressed in terms of its 5- day biochemical oxygen demand (BODs), suspended solids and chemical oxygen demand (COD) (Salvato, 1986). When untreated wastewater is discharge into public drains, they go on to pollute nearby water sources by exerting oxygen demand in the water and causing prolific aquatic growth or depositing toxic substances into water course. All these lead to harming of aquatic life. This in turn will affect both the quality of the water as well as the 
resources derived from these waterbodies (Okafor, 1985). Also the flora and fauna of waters are affected by wastewaters in two basic ways. The first effect is physical; involving altering the aquatic habitat, in terms of water volume and flow velocity, altering the nature of the bed of the water and interfering with the transmission of sunlight through the water. Secondly, and usually more importantly the effects of wastewaters alter the chemical quality of the water.

Other effects wastewater has on receiving stream are: Settleable solids may have adverse effects on stream organisms by covering up the stream bed and forming sludge blankets that will decompose anaerobically with the formation of odourous gases. It may also prevent fish hatching on the streambed and may create an anaerobic enrichment that will hamper bottom dwelling microscopic organism. Suspended solids will give the water turbid complexion limiting light penetration that in turn hampers aquatic vegetation relying on photosynthesis reaction for survival. Large amounts of suspended solid will also increase the requirement for treatment of the water to be used for domestic supply.

If the wastes generated are left untreated, various pollutants which are potentially harmful will be released to the aquatic environment (Uwadia and Ademoroti, 2011). The future of man depends upon the state of his environment. The impact of sewage disposal on the environment has become a threat to the existence of plant and animals and ultimately to the quality of human life. Pollution problem is worse in developing countries like Nigeria where indiscriminate wastewater disposal is mostly practiced. The cost of pollution control is extremely high. Treatment of domestic sewage before disposal helps to prevent pollution of the entire ecosystem and thus preserve our water for beneficial uses.

The type of solid decomposable organic and inorganic matter should dictate the technologies that are applicable in treatment of any particular wastewater (Salvato, 1986).According to Mara (1977), the techniques are divided into 3 groups: primary, secondary (biological treatment) and tertiary treatment.

In this work, the Obafemi Awolowo University, Ile-Ife, oxidation pond (an example of biological treatment) treated effluent and the stream into which it is discharged was studied. The work focused on the characteristics of the untreated effluent, treated effluent and the receiving streams and also compared the stream water before and after the treated effluent discharge to see if there were any significant changes in the water bodies after treated effluent outfall into the stream.

\section{Study Area}

The study area is located in the southwest area of Obafemi Awolowo University campus, Ile Ife Nigeria. The campus lies between latitude $7^{\circ} 30^{\prime} \mathrm{N}-7^{\circ} 32^{\prime} \mathrm{N}$ and longitude $4^{\circ} 30^{\prime} \mathrm{E}-4^{\circ} 32^{\prime} \mathrm{E}$. The oxidation pond measures about $150 \mathrm{~m}$ by $32 \mathrm{~m}$ i.e. $4800 \mathrm{~m}^{2}$ and is about a meter deep. It drains the wastewater from the central campus comprising the hostels and academic area with an estimated population of 30,000 people. It is about $2 \mathrm{~km}$ away from the bustling academy environment. It was constructed in 1967 and became operational the following year. There is an iron-gauze that separate floating objet from entering the pond. Wastes are conveyed through closed sewers whose directions are changed by manhole. The wastewaters are retained in the pond for about two weeks, during which process bacteria, algae, and other microorganisms act to break down the waste.

There are two ponds and they work alternatively. Each pond has a concrete canal measuring about $90 \mathrm{~m}$. The canal drains treated effluent from the ponds to the receiving stream. This stream serves as a source of potable water to the local person outside the University campus and those farming within the university land who depends on it to irrigate their vegetable farm plot during the dry season.

\subsection{Sampling Stations}

Fourteen sampling site were chosen to represent untreated effluent wastewater, treated effluent, receiving stream before and after treated effluent outfall. Station A is represented by locations 1-3 (unimpacted state of the effluent-receiving stream). Station B (location 11) untreated effluent while Stations C1 and C2 is represented by locations 4 and 8 (discharged treated effluent from the sewage Ponds I and II). Stations D1 and D2 (locations 5 and 9 ) is the receiving stream. Station E (represented by location 12) is the impacted stream 2 kilometers away from the ponds. Stations F is represented by locations 6, 7, 10, 13 and 14 (flowing stream and Opa River after the treated effluent discharged).

\section{Materials and Methods}

Sampling was carried out from August 2012 and to January 2013. The fourteen stations were sampled throughout the period, sample were collected fortnightly from each of the stations. Glass reagent bottles of $250 \mathrm{ml}$ capacity were used for collecting dissolved oxygen and BODs samples. Five litres capacity PVC plastic bottles was used for collecting the samples for the other chemical determination while floating object, stopwatch 
and tape rules were used to determine the discharge volume.

\subsection{Sample Analysis}

In-situ Analysis was carried out directly on the samples. $\mathrm{pH}$ and temperature were determined using a $\mathrm{pH}$ meter and thermometer, while dissolved oxygen (DO) concentration of the samples was fixed using Winkler's reagents in the field. All other chemical determinations especially those of plant nutrients $\left(\mathrm{PO}_{4}, \mathrm{NO}_{4}\right.$ and $\left.\mathrm{SO}_{4}\right)$ were carried out in the laboratory. Conductivity was determined at $25^{\circ} \mathrm{C}$. The following parameters were determined titrimetrically: $\mathrm{DO}, \mathrm{BOD}_{5}$, total alkalinity using Standard Sulphuric acid and mixed indicator (APHA, et al, 1995). Organic matter content (estimated as organic carbon x 1.724) was determined by oxidation using chromic acid. Carbon and Magnesium were determined by complexiometric titration using EDTA (Golterman et al, 1978) while $\mathrm{Na}$ and $\mathrm{K}$ were determined using a flame emission analyzer.

Nitrate and otho-phosphates were all determined by Atomic Absorption Spectrophotometer (ASS) according to Csuros, 1997. Most of the analytical methods employed were within the precision range of $10 \%$ or less.

\section{Result and Discussion}

The summary of the fortnightly variation in the physico-chemical quality of the receiving stream, the river, the untreated and treated effluent are presented in Table 1.

Table 1. The annual mean values of physico-chemical parameters from sampling locations

\begin{tabular}{|c|c|c|c|c|c|c|c|c|c|}
\hline \multirow{2}{*}{ Parameter } & \multirow{2}{*}{ Stat. } & \multicolumn{8}{|c|}{ Sample set } \\
\hline & & $\mathrm{A}$ & B & $\mathrm{C} 1$ & $\mathrm{C} 2$ & D1 & $\mathrm{D} 2$ & $\mathrm{E}$ & $\mathrm{F}$ \\
\hline Temp. & mean & 25.0 & 27.8 & 25.6 & 28.4 & 25.1 & 25.7 & 27.8 & 27.7 \\
\hline$\left({ }^{\circ} \mathrm{C}\right)$ & s.d. & 0.5 & 0.52 & 0.89 & 1.34 & 0.51 & 1.01 & 0.5 & 1.41 \\
\hline Turb. & mean & 14.4 & 16.2 & 19 & 43 & 7.8 & 10.6 & 19.5 & 10.9 \\
\hline (NTU) & s.d. & 9.6 & 23.5 & 182 & 76.5 & 3.63 & 6.96 & 30.3 & 10.3 \\
\hline TS & mean & 170 & 409 & 212 & 243 & 161 & 168 & 168 & 137 \\
\hline$(\mathrm{mg} / \mathrm{l})$ & s.d. & 25.5 & 156.6 & 114 & 79 & 26.1 & 25.6 & 48.4 & 32.4 \\
\hline TSS & mean & 27.8 & 32.8 & 29.0 & 23.7 & 21.7 & 19.0 & 21.6 & 21.0 \\
\hline$(\mathrm{mg} / \mathrm{l})$ & s.d. & 13.5 & 29.9 & 20.5 & 14.5 & 11.5 & 7.9 & 13.6 & 10.7 \\
\hline DR & mean & 0.052 & 0.022 & 0.006 & 0.008 & 0.084 & 0.101 & 2.454 & 2.52 \\
\hline$(\mathrm{m} 3 / \mathrm{s}$ & s.d. & 0.038 & 0.005 & 0.001 & 0.007 & 0.063 & 0.079 & 0.722 & 0.750 \\
\hline \multirow{2}{*}{$\mathrm{pH}$} & mean & 7.35 & 4.66 & 6.48 & 5.21 & 7.32 & 7.31 & 7.42 & 7.44 \\
\hline & s.d. & 0.15 & 0.33 & 0.62 & 0.69 & 0.15 & 0.20 & 0.25 & 0.20 \\
\hline Cond. & mean & 194 & 539 & 260 & 398 & 210 & 210 & 163 & 165 \\
\hline$(\mu \mathrm{S} / \mathrm{cm})$ & s.d. & 35.5 & 257 & 140 & 125 & 108 & 75 & 26.9 & 31 \\
\hline TDS & mean & 132 & 352 & 164 & 226 & 146 & 139 & 131 & 129 \\
\hline$(\mathrm{mg} / \mathrm{l})$ & s.d. & 37.9 & 160 & 107 & 68.2 & 15.6 & 22.7 & 31.5 & 31.4 \\
\hline $\mathrm{Ca}$ & mean & 13.4 & 27.9 & 14.6 & 20.5 & 12.6 & 13.9 & 14.5 & 12.7 \\
\hline$(\mathrm{mg} / \mathrm{l})$ & s.d. & 0.72 & 10.5 & 6.07 & 3.00 & 0.69 & 0.81 & 3.43 & 1.92 \\
\hline $\mathrm{Mg}$ & mean & 6.32 & 12.3 & 10.3 & 10.1 & 6.5 & 7.2 & 8.52 & 8.8 \\
\hline$(\mathrm{mg} / \mathrm{l})$ & s.d. & 1.76 & 2.79 & 5.27 & 1.70 & 2.01 & 1.42 & 1.86 & 0.80 \\
\hline $\mathrm{Na}$ & mean & 12.8 & 35.3 & 18.2 & 22.8 & 12.1 & 13.3 & 12.0 & 9.0 \\
\hline$(\mathrm{mg} / \mathrm{l})$ & s.d. & 2.74 & 19.4 & 11.1 & 14.1 & 2.75 & 3.78 & 5.45 & 1.72 \\
\hline K & mean & 4.3 & 14.7 & 5.8 & 8.0 & 4.4 & 4.4 & 4.5 & 3.9 \\
\hline$(\mathrm{mg} / \mathrm{l})$ & s.d. & 2.01 & 10.5 & 5.83 & 6.01 & 2.68 & 2.10 & 2.46 & 1.15 \\
\hline Alk (mg/l & mean & 49 & 22.0 & 46.0 & 44 & 52 & 51 & 88 & 65 \\
\hline $\left.\mathrm{CaCO}_{3}\right)$ & s.d. & 4.58 & 24.9 & 9.75 & 18.8 & 2.56 & 6.67 & 22.0 & 6.8 \\
\hline
\end{tabular}




\begin{tabular}{llllllllll}
$\mathrm{Cl}$ & mean & 16.6 & 55.9 & 22.4 & 30.5 & 15.9 & 15.6 & 9.3 & 9.3 \\
$(\mathrm{mg} / \mathrm{l})$ & s.d. & 3.96 & 40.7 & 12.47 & 17.42 & 4.95 & 4.52 & 1.28 & 1.51 \\
$\mathrm{SO}_{4}$ & mean & 7.4 & 36.0 & 11.5 & 10.8 & 7.2 & 10.7 & 8.1 & 7.3 \\
$(\mathrm{mg} / \mathrm{l})$ & s.d. & 1.86 & 6.3 & 6.12 & 3.93 & 2.98 & 4.93 & 2.98 & 1.60 \\
$\mathrm{DO}$ & mean & 5.76 & 6.32 & 6.32 & 5.00 & 6.18 & 5.86 & 7.13 & 8.00 \\
$(\mathrm{mg} / \mathrm{l})$ & s.d. & 2.32 & 4.27 & 4.27 & 4.13 & 3.07 & 3.27 & 2.54 & 2.82 \\
$\mathrm{O}_{2} \mathrm{sat}$ & mean & 70 & 80 & 77 & 64 & 71.8 & 71.8 & 91 & 102 \\
$(\%)$ & s.d. & 27.5 & 54.6 & 52.3 & 52.4 & 31.9 & 39.4 & 33.4 & 36.8 \\
$\mathrm{BOD}$ & mean & 2.56 & 218 & 44.3 & 90.3 & 3.15 & 3.14 & 3.18 & 2.93 \\
$(\mathrm{mg} / \mathrm{l})$ & s.d. & 0.87 & 49.1 & 13.8 & 40.52 & 1.77 & 1.40 & 0.99 & 1.30 \\
$\mathrm{NO} 3$ & mean & 139 & 159 & 132 & 141 & 149 & 127 & 137 & 125 \\
$(\mu \mathrm{g} / \mathrm{l})$ & s.d. & 52.9 & 59 & 62.2 & 70.6 & 62.3 & 39.7 & 41.5 & 30 \\
$\mathrm{PO}$ & mean & 416 & 1370 & 543 & 691 & 318 & 419 & 349 & 373 \\
$(\mu \mathrm{g} / \mathrm{l})$ & s.d. & 263 & 541 & 476 & 245 & 209 & 257 & 264 & 263 \\
$\mathrm{OM}$ & mean & 1.27 & 3.09 & 2.17 & 3.68 & 1.43 & 1.30 & 1.19 & 1.32 \\
$(\mathrm{mg} / \mathrm{l})$ & s.d. & 0.20 & 1.09 & 0.75 & 2.09 & 0.39 & 0.35 & 0.33 & 0.38 \\
\hline $\mathrm{Leg}$ & & & & & & & &
\end{tabular}

Legend

A. $\quad=$ Receiving stream before treated effluent outfall

$B \quad=$ Untreated effluent wastewater

$C 1 \quad=$ Treated effluent from pond I

$C 2 \quad=$ Treated effluent from pond II

D1 =Impacted treated effluent receiving stream cause by Pond I

D2 =Impacted treated effluent receiving stream cause by Pond II

E $\quad=$ Unimpacted Opa River

$F \quad=$ Impacted Opa River

The untreated effluent wastewater quality was generally higher than the biologically degraded treated effluent wastewater and the water from the receiving stream in virtually all parameters investigated except $\mathrm{pH}$, dissolved oxygen and alkalinity. This was closely followed by the treated effluent quality and the receiving stream and river.

\subsection{Untreated Effluent Quality}

The temperature occurred within the narrow range of $27.0-28.5^{\circ} \mathrm{C}$ with an overall mean of $27.8 \pm 0.52^{\circ} \mathrm{C}$. The $\mathrm{pH}$ was generally acidic varying from 4.13 to 5.11 with an overall average of $4.66 \pm 0.33$ throughout the sampling period.

The strength of domestic sewage is measured in terms of its biochemical oxygen demand (BOD) level. It determines the amount of dissolved oxygen consumed by aerobic bacteria in the decomposition of organic matter in the sewage. The typical wastewater BOD in Nigeria occurred within a range of $200-500 \mathrm{mgl}^{-1}$ (Ogedengbe, 1990) while the value for the present investigated untreated effluent was in the range of $186.4-298.0 \mathrm{mgl}^{-1} \mathrm{thus}^{-}$ indicating a low level of BOD. Using Mara's (1977) classification the untreated effluent can be categorized between weak and medium strength wastewater.

\subsection{Treated Effluent Quality}

The investigated physico-chemical parameters of discharged treated effluent from the two ponds showed appreciable percent reduction in terms of inorganic and organic load when compared to the untreated effluent outfall, varying from one parameter to another. Temperature of the pond A decreased from $27.8^{\circ} \mathrm{C}$ to $25.6^{\circ} \mathrm{C}(7.9 \%$ decrease) while the following parameters decreased by $45 \%$ and above: total solids, conductivity, total dissolved solids, calcium, sodium potassium, alkalinity, chloride, sulphate, dissolved oxygen, BOD and phosphate. In 
general, there was overall improvement of $47.6 \%$ of treated effluent treated in Pond I and $38.7 \%$ in Pond II.

\subsection{Receiving Stream before and after Treated Effluent Outfall}

The $\mathrm{pH}$ values showed the water to be slightly alkaline occurring within the range of 6.80 and 7.69 with mean of 7.31 and 7.32. This is characteristic of most lakes and streams of the world (Akinbuwa, 1999; Akande and Awotoye, 1990; Ekpeyong and Adeniyi, 1996). Temperatures values ranged from $24.5^{\circ} \mathrm{C}$ to $27.2^{\circ} \mathrm{C}$ with an average value of $25.0 \pm 0.50^{\circ} \mathrm{C}$ ). The high temperature of the water is due to long isolation period often experienced in the tropics (Akinbuwa, 1988; Lowernberg and Kunzel, 1992). Other water quality characteristics with result similar to African waters are total solids, total suspended solids and total dissolved solids while biological oxygen demand value are considered low $\left(1.6-5.0 \mathrm{mgl}^{-1}\right)$

According to Practi et al. (1971), the chemical parameters generally used as indices of pollution (BOD, DO, Chloride, $\mathrm{pH}$ and Nitrate) fall in the acceptable range and therefore the water pristiness is not in doubt before the treated effluent outfall.

\section{$\underline{\text { Relationship between sample sets }}$}

\section{Treated effluent receiving stream before and after treated effluent outfall}

The relationship between the impacted and unimpacted sections of the treated effluent receiving stream immediately after outfall caused by Pond I and II are shown in Tables 2 and 3. Although the concentration of the impacted section were higher than unimpacted section, the t-test analysis of the effluent receiving stream before and after treated effluent outfall showed that out of the twenty-one physico-chemical parameters analyzed, only four parameters (turbidity, calcium, alkalinity and percent oxygen saturation) showed significant differences between the two locations. A similar trend was also observed from the treated effluent from Pond II into the receiving stream. The high similarities are as result of their origin and also due to the fact that not only had the untreated effluent been highly degraded it had also been well assimilated by the receiving stream.

Table 2. Relationship between the physico-chemical water quality (before and after the effluent outfall from Pond I)

\begin{tabular}{|c|c|c|c|c|c|c|c|}
\hline \multirow{2}{*}{ Parameter } & \multicolumn{3}{|c|}{ Unimpacted Receiving stream $(\mathrm{n}=10)$} & \multicolumn{3}{|c|}{ Impacted Receiving stream $(\mathrm{n}=10)$} & \multirow{2}{*}{$\begin{array}{l}\text { Student T-stat }(\mathrm{df}=2 \text { and } 18) \\
\mathrm{p}\end{array}$} \\
\hline & mean & s.d. & $\% \mathrm{cv}$ & mean & s.d. & $\% \mathrm{cv}$ & \\
\hline Temp $\quad\left({ }^{\circ} \mathrm{C}\right)$ & 25.0 & 0.5 & 2 & 25.1 & 0.51 & 2 & 0.449 \\
\hline Turb (NTU) & 14.4 & 9.6 & 67 & 7.8 & 3.63 & 47 & 0.033 \\
\hline$(\mathrm{mg} / \mathrm{l})$ & 170 & 25.5 & 21 & 161 & 26.1 & 16 & 0.464 \\
\hline $\mathrm{TSS} \quad(\mathrm{mg} / \mathrm{l})$ & 27.8 & 13.5 & 49 & 21.7 & 11.5 & 53 & 0.151 \\
\hline $\mathrm{DR} \quad\left(\mathrm{m}^{3} / \mathrm{s}\right)$ & 0.052 & 0.038 & 73 & 0.084 & 0.063 & 75 & 0.106 \\
\hline $\mathrm{pH}$ & 7.35 & 0.15 & 2 & 7.32 & 0.15 & 2 & 0.352 \\
\hline Cond. $(\mu \mathrm{S} / \mathrm{cm})$ & 194 & 35.5 & 18 & 210 & 108 & 51 & 0.338 \\
\hline TDS $\quad(m g / l)$ & 132 & 37.9 & 29 & 146 & 15.6 & 11 & 0.285 \\
\hline$(\mathrm{mg} / \mathrm{l})$ & 13.4 & 0.72 & 5 & 12.6 & 0.69 & 5 & 0.013 \\
\hline $\mathrm{Mg} \quad(\mathrm{mg} / \mathrm{l})$ & 6.32 & 1.76 & 28 & 6.5 & 2.01 & 31 & 0.491 \\
\hline$(\mathrm{mg} / \mathrm{l})$ & 12.8 & 2.74 & 21 & 12.9 & 2.75 & 21 & 0.468 \\
\hline$(\mathrm{mg} / \mathrm{l})$ & 4.3 & 2.01 & 47 & 4.4 & 2.68 & 61 & 0.464 \\
\hline $\mathrm{Alk}\left(\mathrm{CaCO}_{3} \mathrm{mg} / \mathrm{l}\right)$ & 49 & 4.58 & 9 & 52 & 2.56 & 5 & 0.035 \\
\hline$(\mathrm{mg} / \mathrm{l})$ & 16.6 & 3.96 & 24 & 15.9 & 4.95 & 31 & 0.407 \\
\hline $\mathrm{SO}_{4} \quad(\mathrm{mg} / \mathrm{l})$ & 7.4 & 1.86 & 25 & 7.2 & 2.98 & 41 & 0.434 \\
\hline DO $\quad(m g / l)$ & 5.76 & 2.32 & 40 & 6.18 & 3.07 & 50 & 0.371 \\
\hline $\mathrm{O}_{2}$ Sat $\quad(\%)$ & 70 & 27.5 & 39 & 71.8 & 31.9 & 44 & 0.000 \\
\hline BOD $\quad(m g / l)$ & 2.56 & 0.87 & 34 & 3.15 & 1.77 & 56 & 0.123 \\
\hline $\mathrm{NO}_{3}(\mu \mathrm{g} / \mathrm{l})$ & 139 & 52.9 & 38 & 149 & 62.3 & 42 & 0.360 \\
\hline $\mathrm{PO}_{4} \quad(\mu \mathrm{g} / \mathrm{l})$ & 416 & 263 & 63 & 318 & 209 & 66 & 0.175 \\
\hline $\mathrm{OM} \quad(\mathrm{mg} / \mathrm{l})$ & 1.27 & 0.20 & 16 & 1.43 & 0.39 & 27 & 0.171 \\
\hline
\end{tabular}


Table 3. Relationship between the physico-chemical water quality of the receiving stream. (before and after effluent outfall from Pond II)

\begin{tabular}{|c|c|c|c|c|c|c|c|}
\hline \multirow{2}{*}{ Parameter } & \multicolumn{3}{|c|}{ Unimpacted Receiving stream $(\mathrm{n}=10)$} & \multicolumn{3}{|c|}{ Impacted Receiving stream $(\mathrm{n}=10)$} & \multirow{2}{*}{$\begin{array}{l}\text { Student T-stat }(\mathrm{df}=2 \text { and } 18) \\
\mathrm{p}\end{array}$} \\
\hline & mean & s.d. & $\% \mathrm{cv}$ & mean & s.d. & $\% \mathrm{cv}$ & \\
\hline Temp $\quad\left({ }^{\circ} \mathrm{C}\right)$ & 25.1 & 0.51 & 2 & 25.7 & 1.01 & 4 & 0.047 \\
\hline Turb (NTU) & 7.8 & 3.63 & 47 & 10.6 & 6.96 & 66 & 0.130 \\
\hline $\mathrm{TS} \quad(\mathrm{mg} / \mathrm{l})$ & 161 & 26.1 & 16 & 168 & 25.6 & 15 & 0.372 \\
\hline $\mathrm{TSS} \quad(\mathrm{mg} / \mathrm{l})$ & 21.7 & 11.5 & 53 & 19.0 & 7.9 & 42 & 0.284 \\
\hline $\mathrm{DR} \quad\left(\mathrm{m}^{3} / \mathrm{s}\right)$ & 0.084 & 0.063 & 75 & 0.101 & 0.079 & 78 & 0.300 \\
\hline $\mathrm{pH}$ & 7.32 & 0.15 & 2 & 7.31 & 0.20 & 3 & 0.457 \\
\hline Cond. $(\mu \mathrm{S} / \mathrm{cm})$ & 210 & 108 & 51 & 210 & 75 & 36 & 0.498 \\
\hline TDS $\quad(\mathrm{mg} / \mathrm{l})$ & 146 & 15.6 & 11 & 139 & 22.7 & 16 & 0.444 \\
\hline$(\mathrm{mg} / \mathrm{l})$ & 12.6 & 0.69 & 5 & 13.9 & 0.81 & 6 & 0.001 \\
\hline $\mathrm{Mg} \quad(\mathrm{mg} / \mathrm{l})$ & 6.5 & 2.01 & 31 & 7.2 & 1.42 & 20 & 0.171 \\
\hline$(\mathrm{mg} / \mathrm{l})$ & 12.9 & 2.75 & 21 & 13.3 & 3.78 & 28 & 0.395 \\
\hline$(\mathrm{mg} / \mathrm{l})$ & 4.4 & 2.68 & 61 & 4.4 & 2.10 & 48 & 0.476 \\
\hline $\mathrm{Alk}\left(\mathrm{CaCO}_{3} \mathrm{mg} / \mathrm{l}\right)$ & 52 & 2.56 & 5 & 51 & 6.67 & 13 & 0.260 \\
\hline $\mathrm{Cl} \quad(\mathrm{mg} / \mathrm{l})$ & 15.9 & 4.95 & 31 & 15.6 & 4.52 & 29 & 0.405 \\
\hline $\mathrm{SO}_{4} \quad(\mathrm{mg} / \mathrm{l})$ & 7.2 & 2.98 & 41 & 10.7 & 4.93 & 46 & 0.063 \\
\hline DO $\quad(m g / l)$ & 6.18 & 3.07 & 50 & 5.86 & 3.27 & 56 & 0.416 \\
\hline $\mathrm{O}_{2}$ Sat $\quad(\%)$ & 71.8 & 31.9 & 44 & 71.8 & 39.4 & 55 & 0.441 \\
\hline BOD $\quad(m g / l)$ & 3.15 & 1.77 & 56 & 3.14 & 1.40 & 45 & 0.362 \\
\hline $\mathrm{NO}_{3} \quad(\mu \mathrm{g} / \mathrm{l})$ & 149 & 62.3 & 42 & 127 & 39.7 & 31 & 0.196 \\
\hline $\mathrm{PO}_{4} \quad(\mu \mathrm{g} / \mathrm{l})$ & 318 & 209 & 66 & 419 & 257 & 61 & 0.179 \\
\hline $\mathrm{OM} \quad(\mathrm{mg} / \mathrm{l})$ & 1.43 & 0.39 & 27 & 1.30 & 0.35 & 27 & 0.274 \\
\hline
\end{tabular}

\subsection{Untreated Effluent Waste Water and Treated Effluent}

The t-test analysis of the data set (Table 4) showed that the untreated effluent wastewater quality was significantly different $(\mathrm{P}<0.05)$ in fifteen out of the twenty-one physico-chemical parameters analyzed. Only the following six parameters: turbidity, TSS, magnesium, percentage oxygen saturation and nitrate did not show any significance difference between the untreated effluents and treated effluent wastewater. The differences between these samples are due to the impact of degraders on the untreated effluent in the oxidation pond. Bacteria and other forms of micro organism had acted on the wastewater significantly breaking them down. 
Table 4. Relationship between the physico-chemical water quality (treated and untreated effluent)

\begin{tabular}{|c|c|c|c|c|c|c|c|}
\hline \multirow{2}{*}{ Parameter } & \multicolumn{3}{|c|}{ Untreated effluent $(\mathrm{n}=10)$} & \multicolumn{3}{|c|}{ Treated effluent $(n=10)$} & \multirow{2}{*}{$\begin{array}{l}\text { Student T-stat }(\mathrm{df}=2 \text { and } 18) \\
\mathrm{P}\end{array}$} \\
\hline & mean & s.d. & $\% \mathrm{cv}$ & mean & s.d. & $\% \mathrm{cv}$ & \\
\hline Temp $\quad\left({ }^{\circ} \mathrm{C}\right)$ & 27.8 & 0.52 & 2 & 25.6 & 0.89 & 3 & 0.000 \\
\hline Turb (NTU) & 16.1 & 23.5 & 146 & 19 & 18.2 & 10 & 0.381 \\
\hline $\mathrm{TS} \quad(\mathrm{mg} / \mathrm{l})$ & 409 & 156.6 & 38 & 212 & 114 & 54 & 0.003 \\
\hline $\mathrm{TSS} \quad(\mathrm{mg} / \mathrm{l})$ & 32.8 & 29.9 & 91 & 29 & 20.5 & 71 & 0.381 \\
\hline $\mathrm{DR} \quad\left(\mathrm{m}^{3} / \mathrm{s}\right)$ & 0.022 & 0.005 & 23 & 0.006 & 0.005 & 83 & 0.000 \\
\hline $\mathrm{pH}$ & 4.66 & 0.33 & 7 & 6.48 & 0.621 & 10 & 0.000 \\
\hline Cond. $(\mu \mathrm{S} / \mathrm{cm})$ & 539 & 257 & 48 & 260 & 140 & 54 & 0.004 \\
\hline TDS $\quad(\mathrm{mg} / \mathrm{l})$ & 352 & 160 & 45 & 164 & 107 & 65 & 0.003 \\
\hline$(\mathrm{mg} / \mathrm{l})$ & 27.9 & 10.5 & 38 & 14.6 & 6.07 & 42 & 0.002 \\
\hline $\mathrm{Mg} \quad(\mathrm{mg} / \mathrm{l})$ & 12.3 & 2.79 & 23 & 10.3 & 5.27 & 51 & 0.154 \\
\hline$(\mathrm{mg} / \mathrm{l})$ & 35.3 & 19.1 & 55 & 18.2 & 11.07 & 61 & 0.014 \\
\hline$(\mathrm{mg} / \mathrm{l})$ & 14.7 & 10.5 & 71 & 5.8 & 5.83 & 101 & 0.018 \\
\hline $\operatorname{Alk}\left(\mathrm{CaCO}_{3} \mathrm{mg} / \mathrm{l}\right)$ & 22.0 & 24.9 & 113 & 46.0 & 9.75 & 21 & 0.008 \\
\hline $\mathrm{Cl} \quad(\mathrm{mg} / \mathrm{l})$ & 55.9 & 40.7 & 73 & 22.4 & 12.47 & 56 & 0.015 \\
\hline $\mathrm{SO}_{4} \quad(\mathrm{mg} / \mathrm{l})$ & 36.0 & 6.3 & 18 & 11.5 & 6.12 & 53 & 0.000 \\
\hline DO $\quad(m g / l)$ & 6.32 & 4.27 & 68 & 6.32 & 4.27 & 68 & 0.500 \\
\hline $\mathrm{O}_{2}$ Sat $\quad(\%)$ & 80 & 54.6 & 68 & 77 & 52.3 & 68 & 0.444 \\
\hline BOD $\quad(m g / l)$ & 218 & 49.1 & 22 & 44.3 & 13.83 & 31 & 0.000 \\
\hline $\mathrm{NO}_{3}(\mu \mathrm{g} / 1)$ & 159 & 59 & 37 & 132 & 62.2 & 47 & 0.162 \\
\hline $\mathrm{PO}_{4} \quad(\mu \mathrm{g} / \mathrm{l})$ & 1370 & 541 & 39 & 543 & 476 & 88 & 0.000 \\
\hline $\mathrm{OM} \quad(\mathrm{mg} / \mathrm{l})$ & 3.09 & 1.09 & 35 & 2.17 & 0.75 & 35 & 0.021 \\
\hline
\end{tabular}

\subsection{Efficiency of the Oxidation Ponds}

Pond I showed an overall efficiency of $30.6 \%$ (Table 5). Efficiency was higher in the rainy season (34.6\%) than in the dry season (25.7\%). The following parameters showed efficiency above 50\%: phosphate, BOD, sulphate, chloride, alkalinity, potassium, TDS and conductivity. Turbidity, $\mathrm{pH}$, alkalinity, DO and percent oxygen saturation showed negative efficiency.

Treatment efficiency showed that in Pond I during the dry season, 12 parameters showed an efficiency of 50\% and above while in the rainy season, efficiency of $50 \%$ and above were recorded for only 5 parameters. Over the annual cycle, $50 \%$ and above were recorded for 10 parameters.

In Pond II, overall efficiency was $19.8 \%$. Efficiency was higher in the dry season $(26.7 \%)$ than in the rainy season (12.9\%). Conductivity, alkalinity, sulphate, BOD and phosphate efficiency were above $50 \%$. The following parameters showed negative efficiency: temperature, turbidity, $\mathrm{pH}$, alkanity, $\mathrm{DO}$, percent oxygen saturation, and organic matter. Pond II showed that 12 parameters had efficiency of $50 \%$ and above while the rainy had just 8 parameters.

On the whole, the oxidation pond showed an overall efficiency of 25.4. The highest efficiency was recorded for alkalinity with an overall average of $109 \%$ closely followed by biological oxygen demand with $78.2 \%$ and sulphate with $70.4 \%$. Relatively very low efficiency values were obtained for organic matter $(10.2 \%)$ and TSS $(8.9 \%)$. The following parameters had mean percent efficiency of $50 \%$ and above: conductivity, potassium, total alkalinity, chloride, sulphate, BOD and phosphate. 
Table 5. Seasonal and mean percent (\%) efficiency of Pond I and II

\begin{tabular}{|c|c|c|c|c|c|c|c|c|c|}
\hline \multirow{2}{*}{ Parameter } & \multicolumn{3}{|l|}{ Pond I } & \multicolumn{3}{|l|}{ Pond II } & \multicolumn{3}{|c|}{ Overall total } \\
\hline & RS (\%) & DS (\%) & Mean (\%) & RS (\%) & DS (\%) & Mean (\%) & RS (\%) & DS (\%) & Mean $(\%)$ \\
\hline Temp $\quad\left({ }^{\circ} \mathrm{C}\right)$ & 6 & 10 & 8 & -5 & 1 & -2.5 & 0.4 & 5 & 3 \\
\hline Turb (NTU) & 22 & -286 & -132 & -150 & -24 & -87 & -64 & -155 & -109 \\
\hline TS (mg/l) & 36 & 56 & 46 & 12 & 59 & 35 & 24 & 57 & 41 \\
\hline TSS (mg/l) & 27 & -42 & -8 & 38 & -5 & 17 & 33 & -24 & 9 \\
\hline $\mathrm{pH}$ & -47 & -32 & -40 & -10 & -20 & -15 & -28 & -25 & -27 \\
\hline Cond. $(\mu \mathrm{S} / \mathrm{cm})$ & 43 & 66 & 54 & 56 & 44 & 50 & 49 & 55 & 52 \\
\hline TDS (mg/l) & 40 & 58 & 49 & 52 & 28 & 40 & 46 & 43 & 45 \\
\hline $\mathrm{Ca}(\mathrm{mg} / \mathrm{l})$ & 35 & 56 & 50 & 13 & 46 & 30 & 24 & 51 & 40 \\
\hline $\mathrm{Mg}(\mathrm{mg} / \mathrm{l})$ & 21 & 11 & 16 & 2 & 39 & 21 & 12 & 25 & 18 \\
\hline $\mathrm{Na}(\mathrm{mg} / \mathrm{l})$ & 32 & 56 & 44 & 24 & 53 & 38 & 30 & 54 & 41 \\
\hline $\mathrm{K}(\mathrm{mg} / \mathrm{l})$ & 53 & 63 & 58 & 37 & 57 & 47 & 45 & 60 & 53 \\
\hline Alkalinity $\left(\mathrm{CaCO}^{3} \mathrm{mg} / \mathrm{l}\right)$ & -77 & -149 & -113 & -109 & -102 & -106 & -93 & -126 & -109 \\
\hline $\mathrm{Cl}(\mathrm{mg} / \mathrm{l})$ & 31 & 71 & 56 & 23 & 64 & 43 & 27 & 67 & 50 \\
\hline $\mathrm{SO}_{4}(\mathrm{mg} / \mathrm{l})$ & 70 & 67 & 68 & 69 & 76 & 72 & 69 & 72 & 70 \\
\hline $\mathrm{DO}(\mathrm{mg} / \mathrm{l})$ & -3 & -40 & -21 & -3 & -60 & -32 & -3 & -50 & -27 \\
\hline $\mathrm{O}_{2}$ Sat $\quad(\%)$ & -7 & -44 & -25 & -29 & -61 & -45 & -108 & -52 & -35 \\
\hline BOD (mg/l) & 80 & 91 & 85 & 49 & 93 & 71 & 64 & 92 & 78 \\
\hline $\mathrm{NO}_{3}(\mu \mathrm{g} / \mathrm{l})$ & 40 & -6 & 17 & 31 & 6 & 19 & 36 & 0.2 & 18 \\
\hline $\mathrm{PO}_{4}(\mu \mathrm{g} / 1)$ & 65 & 58 & 61 & 47 & 51 & 49 & 56 & 55 & 55 \\
\hline $\mathrm{OM}(\mathrm{mg} / \mathrm{l})$ & 28 & 33 & 31 & -13 & -7 & -10 & 7 & 13 & 10 \\
\hline
\end{tabular}

\section{Summary and Conclusion}

The physic-chemical quality of the Obafemi Awolowo University, Ile-Ife, Oxidation Ponds' untreated effluent, treated effluent and treated effluent receiving water bodies was carried out over a period of 6 months from August 1999 to January 2000 (a period covering the two season of the year). The impact of the treated effluent on the receiving stream was highlighted. The physico-chemical water quality of the receiving water bodies meets most of the general water requirements for both domestic and industrial uses (FAO, 1990; Olusola, 2012). The untreated effluent quality was shown to be of biological origin based on the biological oxygen demand, chloride, dissolved oxygen, total solids, $\mathrm{pH}$ and organic matter (Practi et al 1971). The treated effluent showed significant improvement over the raw untreated effluent based on some the parameters assessed.

There was a significant difference $(\mathrm{P}<0.05)$ between the physico-chemical quality of untreated effluent and the treated effluent for the most of the investigated physic-chemical quality. The difference between the discharged treated effluent and the unimpacted section of the receiving waterbodies was also significant $(p<0.05)$ for the most of the physico-chemical parameters.

However, the difference between the impacted and unimmpacted receiving water bodies was not significant ( $>0.05$ ) for most of the parameters with exceptions of turbidity, Ca and TSS.

This work has demonstrated that biological oxidation method of treatment can greatly reduce biologically generated waste as demonstrated by the high percentage reduction in the wastewater load and if harnessed can be extensively used in treating both institutional and municipal wastewater especially in tropical third world countries where there is abundant sunshine and land coupled with its low cost of construction and maintenance. Treatment of these wastes will also significantly reduce loads into the aquatic environment and help to preserve our rivers, streams and canals for sustainable use, a view also expressed in the work of Adejobi and Olorunnimbe (2012). Onsite treatment (within estates, institutions, etc.) will also greatly reduce the cost of collection, transportation and disposal which according to Medina (2002) and Ogwueleka (2009) accounts for 36-50\% of 
municipal operational budgets in third world and developing countries.

\section{References}

Abila, B., \& Kantola, J. (2013). Municipal Solid Waste Management Problems in Nigeria: Evolving knowledge Management Solutions. World Academy of Sci., Eng. and Tech., 78, 313-318.

Adejobi, O. S., \& Olorunnimbe, R. O. (2012). Challenges of Waste Management and Climate Change in Nigeria: Lagos State Metropolis Experience. Afri. J. of Scie. Research, 7(1).

Akande, A. O., \& Awotoye, O. (1990). Some aspects of the ecology of Isiula Lake - a natural aquatic ecosystem in Ado-Ekiti, Nigeria. Nig. J. of Botany, 3, 221-230.

Akinbuwa, O. (1988). The study of the physico-chemical factors and rotifera fauna of Opa Reservoir, Ile-Ife, Nigeria. M. Sc. Thesis. University of Ife, Ile-Ife, Nigeria.

Akinbuwa, O. (1999). The Rotifera fauna and Physico-chemical conditions of Erinle lake and its major inflows at Ede, Osun State, Nigeria. Ph.D Thesis O.A.U, Ile-Ife Nigeria. 333pp.

APHA, AWWA, \& WEF (1995). Standard methods for the examination of water and wastewater (19th ed.). Washington.

Butu, A. W., \& Mshelia, S. S. (2014). Municipal solid waste disposal and environmental issues in Kano metropolis, Nigeria. British Journal of Environmental Sciences, 2(1),1-16.

Csuros, M. (1997). Environmental Sampling Analysis -Lab Manual. Lewis Publication, New York.

Ekpeyong, E., \& Adeniyi, I. F. (1996): Physical and chemical factors and net phytoplankton distribution in some tropical fish ponds. Tropical Freshwater Biology, 5, 43-53.

Food and Agricultural Organization. (1990). Guidelines for irrigation and water standards.

Golterman, R. I., Clymo, R. S., \& Ohnstad, M. A. M. (1978). Methods for physical and chemical Analysis of Freshwater. IBP Handbook No 8. Blackwell Scientific Publication, Oxford.

Kadafa, A. Y., Latifa, A., Abdullahi, H. S., \& Suleiman, W. A. (2013): Comparative Assessment of the municipal Solid Waste Management Services. Nature and Science, 11(6), 154-164.

Lowenberg, U., \& Kunzel, T. (1992). Invertebrates and the hydrobiology of the lower Cross River, Nigeria. Animal Research and Development, 35, 73-85. Institute of Scientific Cooperation, Tubingen.

Mara, D. D. (1977). Wastewater treatment in hot climates. In R. Feacham, M. Mc Garry, \& D. D. Mara, (Eds.), Water, Wastes and Health in Hot climates. John Wiley and Sons, New York.

Medina, M. (2002). Municipal Solid Waste Management in the third world cities; Lessons learned and proposal for improvement. J. of Human Settlement Development, 1(5).

Miller, G. T. (1994). Living in the Environment; Belmont, California - Wadsworth Publishing Company.

Ogedengbe, O. (1990). Technologies for Industrial waste Management. Paper for a short certificate course workshop on Environmentally Friendly Technologies for Management of Waste, Inst. of Ecology and Environmental Studies and the UNICECS, O.A.U. Ile-Ife, Nigeria.

Ogwueleka, A. (2009). Municipal Solid Waste Management Characteristics and Management in Nigeria. Iran J. Environ. Health Sci. Eng., 6(3), 173-180.

Okafor, O. (1985). Aquatic and waste microbiology. $4^{\text {th }}$ Dimension Publishers, Enugu, Nigeria.

Olusola, A. A. (2012). Assessment of surface water receiving sewage effluents for gardening irrigation purposes: A case study of Ona River in Ibadan Southwest Local Government Area of Oyo State, Nigeria. ARPN Journal of Earth Sciences, 1(1).

Omole, F. K., \& Alakinde, M. K. (2013). Managing the Unwanted Materials: The Agony of Solid Waste Management in Ibadan Metropolis, Nigeria. International Journal of Education and Research, 1(4), 1-12.

Practi, L., Pavenello, R., \& Pasarin, P. (1971). Assessment of surface water quality by a single index of pollution. Water Research, 5, 741-751. http://dx.doi.org/10.1016/0043-1354(71)90097-2

Salvato, J. A. (1986). Environmental Engineering and Sanitation. A Wiley- Intescience publication. John Wiley and Sons, New York.

Uwadia, I. E., \& Ademoroti, C. M. A. (2011). Characterisation of domestic sewage from an estate in Warri, Nigeria. International J. of Chemistry, 3(3). http://dx.doi.org/10.5539/ijc.v3n3p81 


\section{Copyrights}

Copyright for this article is retained by the author(s), with first publication rights granted to the journal.

This is an open-access article distributed under the terms and conditions of the Creative Commons Attribution license (http://creativecommons.org/licenses/by/3.0/). 